\title{
Gluconobacter oxydans subsp. sphaericus, New Subspecies Isolated From Grapes
}

\author{
MINORU AMEYAMA \\ Department of Applied Microbiology, Faculty of Agriculture, Yamaguchi University, Yamaguchi, Japan
}

A new subspecies, Gluconobacter oxydans subsp. sphaericus, is described. This subspecies differs from the other subspecies of $G$. oxydans, the only species recognized in the genus Gluconobacter, both in its morphology and in its vitamin requirement for growth: the cells of the new subspecies are spherical at any age of culture and in all environments tested, and the organism requires nicotinic acid for growth; it differs from all other gluconobacters in that it does not require pantothenic acid. The type strain is IFO 12467.

During a survey by Ameyama in 1966 of the acetic acid bacteria, a hitherto undescribed organism was isolated from fresh grapes. The cells of this organism were spherical at any age of culture and in all media tested. With but a few exceptions, the organism had the physiological and biochemical characteristics of organisms belonging to the species Gluconobacter oxydans. The present paper describes the results of a taxonomic study of this new organism.

\section{MATERIALS AND METHODS}

Bacterial strains. The strains studied and their sources are listed in Table 1. The strains other than the strain of the newly isolated organism were obtained from the Institute of Fermentation, Osaka (IFO). In the tables of this paper, these strains are listed by the names under which they were received.

Media. Stock cultures were maintained on potato-glycerol (PG) slants. This medium was prepared as follows: $200 \mathrm{~g}$ of freshly sliced potato was boiled in 1 liter of tap water and autoclaved for 10 min at $2 \mathrm{~kg} / \mathrm{cm}^{2}$; dried yeast extract (Oriental Yeast Co.) (10 g), polypeptone $(10 \mathrm{~g})$, glycerol $(20 \mathrm{~g})$, and glucose $(5 \mathrm{~g})$ were added to the potato extract.

Media used for determining cultural characteristics were PG medium, 0.8\% nutrient broth (Difco) containing $1 \%$ glycerol, and a synthetic medium (S) containing $5 \mathrm{~g}$ of carbohydrate as the sole carbon source, $5 \mathrm{~g}$ of vitamin-free Casamino Acids (Difco), $0.4 \mathrm{mg}$ of nicotinic acid, $0.5 \mathrm{~g}$ of $\mathrm{KH}_{2} \mathrm{PO}_{4}, 0.5 \mathrm{~g}$ of $\mathrm{K}_{2} \mathrm{HPO}_{4}, 0.2 \mathrm{~g}$ of $\mathrm{MgSO}_{4} \cdot 7 \mathrm{H}_{2} \mathrm{O}$, and $10 \mathrm{mg}$ each of $\mathrm{NaCl}, \mathrm{FeSO}_{4}$, and $\mathrm{MnSO}_{4} 7 \mathrm{H}_{2} \mathrm{O}$ in 1 liter. All media were sterilized for $30 \mathrm{~min}$ at $2 \mathrm{~kg} / \mathrm{cm}^{2}$.

Vitamin requirement determinations. The effect on growth of nicotinic acid, pantothenic acid, $p$ aminobenzoic acid, and thiamine $(0.4 \mathrm{mg} / \mathrm{liter})$ was examined upon their addition to glucose-S medium. Inocula were taken from cultures grown to the stationary phase $(48 \mathrm{~h})$ in $\mathrm{PG}$ medium, which had been prepared by dispensing $2.5-\mathrm{ml}$ quantities into $8-\mathrm{ml}$ centrifuge tubes and autoclaving. The inocula were washed twice with sterilized water by centrifugation and suspended in the same water. One drop of the suspension served as inoculum for a test tube of the culture medium, which was dispensed in 6-ml quantities into test tubes ( 18 by $150 \mathrm{~mm}$, for use in colorimetry). The cultures were incubated with reciprocal shaking at $30 \mathrm{C}$ for 3 days. Growth was measured by optical density in a Hitachi model EBO-B photometer with a $660-\mathrm{nm}$ filter.

Synchronous culture. Cells grown for 2 days on PG slants and washed twice with sterilized water were inoculated into nicotinic acid-free glycerol-S medium. After incubation for $3 \mathrm{~h}$, sterilized nicotinic acid solution (up to $0.4 \mathrm{mg} / \mathrm{liter}$ ) was added to the cultures.

Oxidation of carbohydrates and amino acids. Oxidation of carbohydrates and amino acids was carried out in a conventional Warburg apparatus at $30 \mathrm{C}$. Each Warburg vessel contained $1.0 \mathrm{ml}$ of cell suspension, $1.5 \mathrm{ml}$ of $0.067 \mathrm{M}$ phosphate buffer $(\mathrm{pH}$ $6.0), 0.3 \mathrm{ml}$ of substrate solution, and $0.2 \mathrm{ml}$ of $15 \%$ $\mathrm{KOH}$ (in the center well). The substrate solution contained $30 \mu \mathrm{mol}$ of carbohydrate or $5 \mu \mathrm{mol}$ of amino acid. Substrates examined were glucose, sodium succinate, sodium acetate, ethanol, DL-alanine, sodium L-glutamate, and L-serine.

Detection of 2,5-diketogluconate and $\gamma$-pyrone compounds. Cells were inoculated in $\mathrm{S}$ medium containing $2 \%$ sodium gluconate. The cultures were incubated with reciprocal shaking at $30 \mathrm{C}$ for 2 days. The cells were removed by centrifugation, and the supernatant was subjected to paper chromatography. 2,5-Diketogluconate on paper chromatograms was detected with 2,3,5-triphenyl-tetrazolium-chloride and $p$-anisidine as the developing agents (7). With these developing agents, 2- and 5-ketogluconates were also detected. $\gamma$-Pyrone compounds were detected with ferric chloride as the developing agent (1).

Microscope observations. Bacteria were stained with the Ziehl carbol-fuchsin and the Hucker Gramstaining solutions and observed with a light microscope. The presence of flagella was determined by the Leifson staining method (9) and also by electron microscopy. For electron microscopy, cells grown on $\mathrm{PG}$ slant cultures for 18 to $24 \mathrm{~h}$ at $30 \mathrm{C}$ were subjected to observation with an electron microscope. After having been shadowed with germanium, the 
TABLE 1. Strains studied and their sources

\begin{tabular}{|c|c|}
\hline Strain & Source \\
\hline \multicolumn{2}{|l|}{ Acetobacters } \\
\hline \multicolumn{2}{|l|}{$\begin{array}{c}\text { Acetobacter aceti subsp. } \\
\text { aceti }\end{array}$} \\
\hline (A. aceti) & IFO 3281 \\
\hline \multicolumn{2}{|l|}{$\begin{array}{l}\text { A. aceti subsp. liquefa- } \\
\text { ciens }\end{array}$} \\
\hline (G. liquefaciens) & IFO 12388 \\
\hline \multicolumn{2}{|l|}{$\begin{array}{l}\text { A. pasteurianus subsp. } \\
\text { ascendens }\end{array}$} \\
\hline (A. ascendens) & IFO 3188 \\
\hline \multicolumn{2}{|l|}{$\begin{array}{l}\text { Not described in the 8th } \\
\text { ed. of Bergey's } \\
\text { Manual }\end{array}$} \\
\hline A. rancens & IFO 3298 \\
\hline A. acetigenus & IFO 3280 \\
\hline A. aurantium & IFO 3246 \\
\hline \multicolumn{2}{|l|}{ Gluconobacters } \\
\hline Gluconobacter oxydans & \\
\hline (G. oxydans) & IFO 3189,3287 \\
\hline \multicolumn{2}{|l|}{$\begin{array}{c}\text { G. oxydans subsp. } \\
\text { industrius }\end{array}$} \\
\hline (G. industrius) & IFO 3260 \\
\hline (G. capsulatus) & IFO 3462 \\
\hline \multicolumn{2}{|l|}{$\begin{array}{l}\text { G. oxydans subsp. } \\
\text { suboxydans }\end{array}$} \\
\hline (G.gluconicus) & IFO 3171,3286 \\
\hline (G. dioxyacetonicus) & IFO $3271,3272,3273$ \\
\hline (G. nonoxygluconicus) & IFO 3276 \\
\hline (G. cerinus) & IFO $3262,3263,3264$ \\
\hline $\begin{array}{l}\text { (G. cerinus) var. } \\
\text { (ammoniacus) }\end{array}$ & IFO 3267 \\
\hline (G. albidus) & IFO 3251,3252 \\
\hline (G. suboxydans) & IFO 3289,3291 \\
\hline $\begin{array}{l}\text { (G. suboxydans) var } \\
\alpha\end{array}$ & IFO 3257 \\
\hline $\begin{array}{c}\text { (G. oxydans) subsp. } \\
\text { melanogenes }\end{array}$ & \\
\hline (G. melanogenus) & IFO 3292,3293 \\
\hline (G. rubiginosus) & IFO 3243,3244 \\
\hline $\begin{array}{c}\text { (G. oxydans) subsp. } \\
\text { sphaericus } \\
\text { subsp. } \mathrm{n} .\end{array}$ & Fresh grapes \\
\hline
\end{tabular}

cells were viewed in a Hitachi model HS-6 electron microscope.

\section{RESULTS}

The gram-negative, diffusible-pigment-producing strain isolated from fresh grapes was similar to Gluconobacter oxydans subsp. melanogenes and Acetobacter aceti subsp. liquefaciens. The physiological and biochemical characteristics of the grape strain were compared with those of other acetic acid bacteria (Gluconobacter and Acetobacter).

The results of aerobic growth and other physiological tests are presented in Tables 2 and 3 . Cultural characteristics are given in the de-
TABLE 2. Aerobic growth of Gluconobacter oxydans subsp. sphaericus with various substrates

\begin{tabular}{lc||lc}
\hline \multicolumn{1}{c}{ Substrate } & Growth & Substrate & Growth \\
\hline Ethanol & + & Fructose & + \\
Butanol & - & Sorbose & + \\
Glycerol & + & Mannitol & + \\
DL-Arabinose & - & Sorbitol & + \\
Xylose & + & Sucrose & + \\
Rhamnose & - & Maltose & - \\
Glucose & + & Starch & - \\
Galactose & + & Dextrin & - \\
Mannose & + & Inulin & - \\
\hline
\end{tabular}

scription of this new strain presented below.

The results given in the tables agree with those obtained with hitherto described organisms belonging to the genus Gluconobacter.

Vitamin requirement tests for growth. Ameyama and Kondo (3) tested the vitamin requirement for growth of the acetic acid bacteria and reported that gluconobacters require one or more vitamins but acetobacters do not require any. Gluconobacters always require pantothenic acid (some strains require nicotinic acid, $p$-aminobenzoic acid, and/or thiamine in addition), but they do not require vitamins $B_{2}$, $\mathrm{B}_{6}, \mathrm{~B}_{12}$, folic acid, biotin, or inositol. Therefore, in this study, nicotinic acid, pantothenic acid, $p$-aminobenzoic acid, and thiamine were examined for their effect, if any, on the growth of the newly isolated strain.

The experimental results are shown in Tables 4 and 5 . The newly isolated strain required only nicotinic acid and thus differed from all other strains belonging to the genus Gluconobacter. Growth of the newly isolated strain was satisfied by the addition of at least $0.1 \mathrm{mg}$ of nicotinic acid per liter to the medium (Fig. 1).

Oxidation of carbohydrates and amino acids. As described previously $(2,4,8,10)$, gluconobacters do not oxidize pyruvate, acetate, or members of the Krebs cycle. Furthermore, they do not oxidize amino acids $(5,6)$.

The results of testing for the oxidation of carbohydrates and amino acids are presented in Table 6 . From these results, the newly isolated strain was clearly identified as belonging to Gluconobacter.

Detection of 2,5-diketogluconate and $\gamma$ pyrone compounds. To compare the newly isolated strain with Gluconobacter oxydans subsp., melanogenes ( $G$. melanogenus IFO 3293), Acetobacter aceti subsp. liquefaciens ( $G$. liquefaciens IFO 12388), and $A$. aurantium IFO $3246(4,8)$, cultures of the strains were incubated in sodium gluconate-S medium and the excreted products were detected by paper chromatography. All four of the pigment-producing strains 
TABLE 3. Physiological characteristics of Gluconobacter oxydans subsp. sphaericus

\begin{tabular}{lcl}
\multicolumn{1}{c}{ Characteristic } & Result & Medium \\
\hline Catalase & + & PG \\
Amylase & - & PG with $2 \%$ starch \\
Reaction in milk & - & Litmus milk with 40 mg of \\
& & nicotinate per liter \\
Nitrite production & \pm & Glycerol-S \\
Indole production & - & Glycerol-S \\
Hydrogen sulfide production & - & Glycerol-S \\
Growth with $12 \%$ NaCl & - & PG \\
Voges-Proskauer & \pm & Glucose-S \\
Methyl red & + & Glucose-S \\
Pigment formation & Red brown & Glucose-S \\
Oxygen demand & - & Glycerol-S \\
Motility & Strictly aerobic & PG \\
\hline
\end{tabular}

TABLE 4. Vitamin requirements for growth of Gluconobacter oxydans subsp. sphaericus ${ }^{a}$

\begin{tabular}{|c|c|c|c|c|}
\hline \multicolumn{4}{|c|}{$\begin{array}{l}\text { Vitamins added to } \\
\text { glucose-S medium }\end{array}$} & \multirow{2}{*}{$\begin{array}{l}\text { Optical } \\
\text { density }\end{array}$} \\
\hline NA & $\mathrm{PA}$ & PABA & $\mathbf{B}_{1}$ & \\
\hline $\mathrm{x}$ & $\mathrm{x}$ & $\mathbf{x}$ & $\mathrm{x}$ & 0.354 \\
\hline $\mathrm{x}$ & $\mathrm{x}$ & $\mathrm{x}$ & & 0.323 \\
\hline $\mathrm{x}$ & $\mathrm{x}$ & & $\mathrm{x}$ & 0.350 \\
\hline $\mathrm{x}$ & & $x$ & $\mathrm{x}$ & 0.360 \\
\hline \multirow[t]{3}{*}{$\mathrm{x}$} & & & & 0.355 \\
\hline & $x$ & $\mathrm{x}$ & $\mathrm{x}$ & 0.020 \\
\hline & & & & 0.027 \\
\hline
\end{tabular}

"Symbols and abbreviations: $x$, vitamin added; NA, nicotinic acid; PA, pantothenic acid; PABA, $p$ aminobenzoic acid; $\mathrm{B}_{1}$, thiamine. used in this experiment produced 2- and 5ketogluconates, 2,5-diketogluconate, and one or more $\gamma$-pyrone compounds.

Morphological characteristics. As described in Bergey's Manual of Determinative Bacteriology (7th ed.), individual cells of acetic acid bacteria are generally ellipsoidal to rod shaped, and the spherical cells may be considered to be a kind of involution form. Cells of the newly isolated strain, however, are always spherical, with a diameter of 1.3 to $1.4 \mu \mathrm{m}$, in any growth phase and in any medium (Fig. 2). One of the cells shown in Fig. 2 appears to be undergoing fission. Observation of old cultures in the light microscope revealed that dividing cells sometimes appeared rod shaped. The spherical shape of the cells was confirmed by

TABLE 5. Vitamin requirements for growth of gluconobacters ${ }^{a}$

\begin{tabular}{|c|c|c|c|c|}
\hline \multirow{2}{*}{ Strain } & \multicolumn{4}{|c|}{ Vitamin required for growth } \\
\hline & NA & PA & PABA & $\mathrm{B}_{1}$ \\
\hline G. oxydans IFO 3287 & $\mathrm{x}$ & $\mathrm{x}$ & & \\
\hline G. industrius IFO 3260 & & $\mathrm{x}$ & $\mathrm{x}$ & \\
\hline G. capsulatus IFO 3462 & $\mathbf{x}$ & $\mathrm{x}$ & & \\
\hline G. gluconicus IFO 3286 & & $\mathrm{x}$ & & \\
\hline G. dioxyacetonicus IFO 3272 & & $\mathbf{x}$ & $\mathbf{x}$ & \\
\hline IFO 3273 & $\mathbf{x}$ & $\mathrm{x}$ & & \\
\hline G. nonoxygluconicus IFO 3276 & & $\mathrm{x}$ & $x$ & \\
\hline G. cerinus IFO 3262 & & $\mathrm{x}$ & $\mathrm{x}$ & \\
\hline IFO 3263,3264 & & $\mathrm{x}$ & & \\
\hline G. cerinus var. ammoniacus IFO 3267 & $\mathrm{x}$ & $\mathrm{x}$ & $\mathrm{x}$ & $\mathrm{x}$ \\
\hline G. albidus IFO 3251 & & $\mathrm{x}$ & $\mathrm{x}$ & \\
\hline IFO 3252 & $\mathrm{x}$ & $\mathrm{x}$ & & \\
\hline G. suboxydans IFO 3289,3291 & & $\mathrm{x}$ & $\mathbf{x}$ & \\
\hline G. melanogenus IFO 3292 & $\mathrm{x}$ & $\mathrm{x}$ & & $\mathrm{x}$ \\
\hline IFO 3293 & $\mathrm{x}$ & $\mathrm{x}$ & & \\
\hline G. rubiginosus IFO 3243 & $\mathrm{x}$ & $\mathrm{x}$ & & \\
\hline IFO 3244 & $\mathrm{x}$ & $\mathrm{x}$ & & $x$ \\
\hline G. oxydans subsp. sphaericus subsp. n. & $\mathbf{x}$ & & & \\
\hline
\end{tabular}

a Symbols and abbreviations: $\mathrm{x}$, vitamin required; NA, nicotinic acid; PA, pantothenic acid; PABA, $p$ aminobenzoic acid; $B_{1}$, thiamine. 
successive observations on many kinds of media during the 9 years of study on this organism since it was isolated from fresh grapes in 1966 .

Synchronous culture. As mentioned above, some older cells appeared to be rod shaped under a light microscope. Therefore, to confirm that the cell shape is spherical, growing cells were observed in synchronous culture inoculated from old PG slants. These cells, even under a light microscope, were all sphere shaped

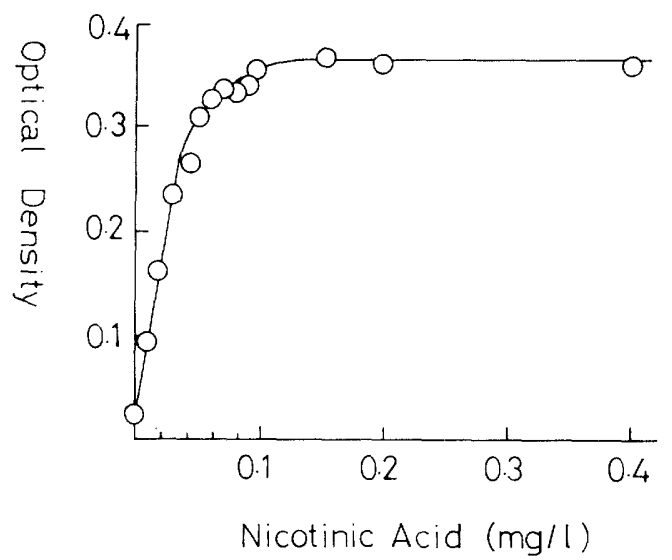

FIG. 1. Relation between the growth of Gluconobacter oxydans subsp. sphaericus, expressed in units of optical density, and concentration of nicotinic acid in glucose-S medium. immediately after fission, and the cell shape was always spherical in any stage of one generation (generation time: about $3 \mathrm{~h}$ ) up to the next fission.

\section{DISCUSSION}

The newly isolated bacterium described here is very similar physiologically and biochemically to organisms belonging to the genus Gluconobacter (Tables 2, 3, and 6). It is placed in the genus Gluconobacter Asai as a new subspecies of $G$. oxydans because it is a strict aerobe, is catalase positive, is methyl red positive, grows well between $\mathrm{pH} 3.5$ and 6.0 , and oxidizes ethanol to acetic acid and glucose to ketogluconates via gluconate, but not succinate, acetate, or alanine. This organism differs from other subspecies of the species G. oxydans heretofore described in its spherical cell shape and in its distinctive vitamin requirement for growth. Table 7 presents the characteristics which differentiate the five subspecies of $G$. oxydans from each other and from a pigmentproducing acetobacter.

The new organism produces the same diffusible pigment and the same $\gamma$-pyrone compounds from glucose or gluconate as do $G$. oxydans subsp. melanogenes, A. aceti subsp. liquefaciens, and A. aurantium. As shown in Table 6 , strains producing the same pigment occur in both Acetobacter and Gluconobacter. For this

TABLE 6. Oxidation of carbohydrates and amino acids by acetic acid bacteria

\begin{tabular}{|c|c|c|c|c|c|c|c|}
\hline \multirow[b]{2}{*}{ Strain } & \multicolumn{7}{|c|}{ Oxidative activity $\left(\mathrm{Q}_{\mathrm{O}_{2}}\right)$ for } \\
\hline & Glucose & $\begin{array}{l}\text { Suc- } \\
\text { cinate }\end{array}$ & Acetate & Ethanol & $\begin{array}{l}\text { Ala- } \\
\text { nine }\end{array}$ & $\begin{array}{l}\text { Glu- } \\
\text { ta- } \\
\text { mate }\end{array}$ & Serine \\
\hline \multicolumn{8}{|l|}{ Acetobacters } \\
\hline Acetobacter aceti IFO 3281 & 100 & 250 & 110 & 300 & .15 & 1 & 1 \\
\hline Gluconobacter liquefaciens ${ }^{a}$ IFO 12388 & 108 & 110 & 100 & 120 & 5 & 1 & 4 \\
\hline Acetobacter ascendens IFO 3188 & 44 & 70 & 13 & 106 & 10 & 1 & 3 \\
\hline A. rancens IFO 3298 & 84 & 227 & 80 & 230 & 8 & 1 & 1 \\
\hline A. kuetzingianus IFO 3222 & 130 & 195 & 100 & 200 & 5 & 1 & 2 \\
\hline A. acetigenum IFO 3280 & 60 & 198 & 100 & 235 & 7 & 2 & 3 \\
\hline A. aurantium ${ }^{2}$ IFO 3246 & 160 & 130 & 40 & 150 & 7 & 1 & 6 \\
\hline \multicolumn{8}{|l|}{ Gluconobacters } \\
\hline Gluconobacter oxydans IFO 3189 & 188 & 0 & 0 & 220 & 0 & 0 & 0 \\
\hline G. capsulatus IFO 3462 & 150 & 0 & 0 & 210 & 0 & 0 & 0 \\
\hline G. gluconicus IFO 3171 & 240 & 0 & 0 & 288 & 0 & 0 & 0 \\
\hline G. dioxyacetonicus IFO 3271 & 202 & 0 & 0 & 242 & 0 & 0 & 0 \\
\hline G. cerinus IFO 3264 & 206 & 0 & 0 & 289 & 0 & 0 & 0 \\
\hline G. albidus IFO 3251 & 212 & 0 & 0 & 276 & 0 & 0 & 0 \\
\hline G. suboxydans var. $\alpha$ IFO 3257 & 200 & 0 & 0 & 104 & 0 & 0 & 0 \\
\hline G. melanogenus ${ }^{a}$ IFO 3292 & 222 & 0 & 0 & 200 & 0 & 0 & 0 \\
\hline G. rubiginosus" IFO 3243 & 200 & 0 & 0 & 180 & 0 & 0 & 0 \\
\hline G. oxydans subsp. sphaericus ${ }^{a}$ & 200 & 0 & 0 & 220 & 0 & 0 & 0 \\
\hline
\end{tabular}

\footnotetext{
" Produce diffusible pigment in glucose-S medium.
} 


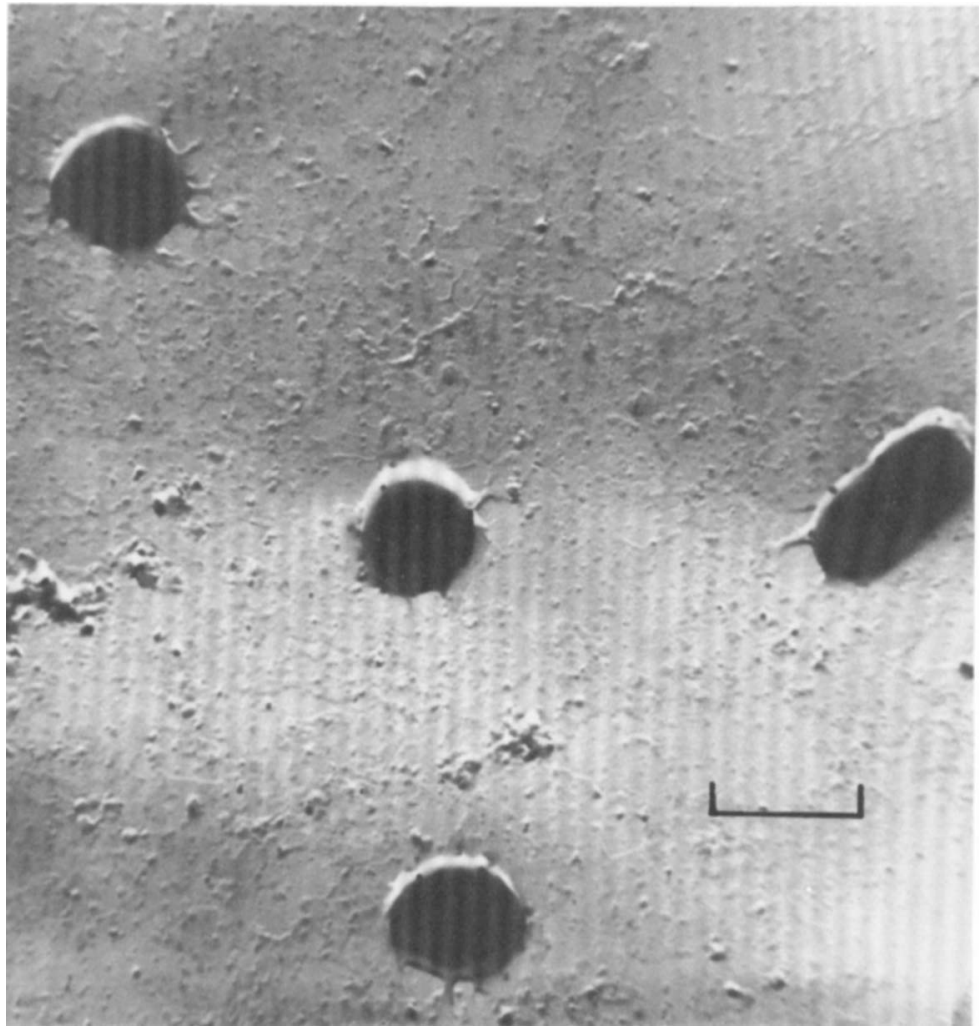

FIG. 2. Electron micrograph of Gluconobacter oxydans subsp. sphaericus IFO 12467, showing spherical shape. Bar indicates $2 \mu \mathrm{m}$.

TABLE 7. Characteristics useful for differentiating between the five subspecies of Gluconobacter oxydans and Acetobacter aceti subsp. liquefaciens

\begin{tabular}{|c|c|c|c|c|c|c|}
\hline \multirow{2}{*}{ Differentiating characteristics } & \multicolumn{5}{|c|}{ G. oxydans subsp: } & \multirow{2}{*}{$\begin{array}{l}\text { A. acet } \\
\text { subsp. } \\
\text { lique- } \\
\text { faciens }\end{array}$} \\
\hline & oxydans & industrius & $\begin{array}{l}\text { sub- } \\
\text { oxydans }\end{array}$ & $\begin{array}{l}\text { melano- } \\
\text { genes }\end{array}$ & sphaericus & \\
\hline Cell shape & Rod & Rod & Rod & Rod & Sphere & Rod \\
\hline $\begin{array}{l}\gamma \text {-Pyrone production from } \\
\text { glucose }\end{array}$ & - & - & - & + & + & + \\
\hline \multicolumn{7}{|l|}{$\begin{array}{l}\text { Vitamin requirement for } \\
\text { growth: }\end{array}$} \\
\hline Pantothenic acid & + & + & + & + & - & - \\
\hline Nicotinic acid & \pm & \pm & \pm & \pm & + & - \\
\hline $\begin{array}{l}\text { Polysaccharide formation from } \\
\text { sucrose or dextrin }\end{array}$ & - & + & - & - & - & - \\
\hline
\end{tabular}

reason, the new organism should not be placed in $G$. oxydans subsp. melanogenes.

Gluconobacter oxydans subsp. sphaericus subsp. n.

sphaéri.cus. Gr. adj. sphaericus spherical.

Spheres, 1.3 to $1.4 \mu \mathrm{m}$ in diameter, occurring singly. Gram negative. Nonmotile.

Catalase positive.
Gelatin stab: Uniform line of puncture and no liquefaction.

Agar colonies: Opalescent, circular, pulvinate, smooth, entire.

Agar slant: Opalescent, filiform, smooth, raised,

Broth: Ring surface growth, slight clouding, and scanty compact sediment. 
Grows very well between pH 3.5 and 6.0 .

Nicotinic acid, but not pantothenic acid, required for growth.

Strict aerobe.

Oxidizes glycerol, xylose, glucose, galactose, mannose, fructose, sorbose, sorbitol, mannitol, and sucrose.

Oxidizes ethanol to acetic acid.

Does not oxidize acetic acid, succinic acid, DLalanine, L-glutamic acid, or L-serine.

Pigment, $\gamma$-pyrone compounds, and 2,5-diketogluconate are produced from glucose or gluconate.

The type strain has been deposited in the Institute of Fermentation, Osaka (IFO) under the number 12467. This strain was isolated in 1966 from fresh grapes. Because the subspecies description given above is based on a single strain, the type strain, it serves also as the description of the type strain.

\section{REPRINT REQUESTS}

Address reprint requests to: Dr. M. Ameyama, Dept. of Applied Microbiology, Faculty of Agriculture, Yamaguchi University, Yamaguchi, Japan.

\section{LITERATURE CITED}

1. Aida, K., T. Kojima, and T. Asai. 1955. Studies on oxidative fermentation. I. On the formation of new substances of positive ferric chloride reaction by Gluconoacetobacter liquefaciens. J. Gen. Appl. Microbiol. 1:18-29.

2. Ameyama, M., and K. Kondo. 1965. Carbohydrate metabolism by the acetic acid bacteria. IV. On the patterns of carbohydrate oxidizabilities and their variation. J. Agric. Chem. Soc. Jpn. 39:427-435.

3. Ameyama, M., and K. Kondo. 1966. Carbohydrate metabolism by the acetic acid bacteria. V. On the vitamin requirements for growth. Agric. Biol. Chem. 30:203-211.

4. Ameyama, M., and K. Kondo. 1967. Carbohydrate metabolism by the acetic acid bacteria. VI. Characteristics of the intermediate type strains. Agric. Biol. Chem. 31:724-737.

5. Janke, A., R. G. Janke, and S. Perczel. 1963. Beiträge zur Kenntnis des Abbaues der Aminosäuren durch Essigsäurebakterien. Arch. Mikrobiol. 45:7-26.

6. Joubert, J. J., W. Bayens, and J. De Ley. 1961. The catabolism of amino acids by acetic acid bacteria. Antonie van Leeuwenhoek J. Microbiol. Serol. $27: 151-160$.

7. Katznelson, H., S. W. Tanenbaum, and E. L. Tatum. 1953. Glucose, gluconate and 2-ketogluconate oxidation by Acetobacter melanogenum. J. Biol. Chem. $204: 43-59$.

8. Kondo, K., and M. Ameyama. 1958. Carbohydrate metabolism by Acetobacter species. I. Oxidative activity for various carbohydrates. Bull. Agric. Chem. Soc. Jpn. 22:369-372.

9. Leifson, E. 1960. Atlas of bacterial flagellation, p. 3. Academic Press Inc., New York.

10. Rainbow, C., and G. W. Mitson. 1953. Nutritional requirements of acetic acid bacteria. J. Gen. Microbiol. 9:371. 